\title{
Host-Country Related Risk Factors in International Construction: Meta-Analysis
}

\author{
Uluslararası Inşaat Sektöründe Ülkeye Özgü \\ Risk Faktörleri Üzerine Meta Analizi
}

Güzin AYDOGAN,'1 Almula KÖKSAL²

\section{ABSTRACT}

Internationalization has been on the agenda of construction firms as a strategic option in global competition. Due to globalization every sector including the construction industry has faced with high levels of competitiveness, uncertainty, and risk. International construction involves common risks to domestic construction, as well as risks that are related to the host country. These risks have serious effects on the performance of international projects. Since the sustainable competitiveness of international contractors depends largely on the effective management of these risks, their assessment becomes vital for the success of international contractors. The main aim of this study is to analyse the risks for international construction projects that are related to the host country. Meta-analysis technique is used in order to determine these risks. This paper, therefore, reviews the literature that has been published in four most respected construction and management journals, these being; Journal of Construction Engineering and Management, Journal of Management in Engineering, Construction Management and Economics, and International Journal of Project Management for the period of 2000-2010. International construction risk assessment models are also reviewed within the context of this study, since host country related risk factors were found to have serious effects on the profitability of international contractors due to literature review. As a result; political stability, law and regulations, exchange rate risk, cultural differences, inflation, expropriation, tax discrimination, language barrier, bribery and corruption, force majeure, and societal conflicts in the host country are found to be the most important risk factors in international construction. Findings of this study can be used in risk assessment models for international construction projects.

\section{ÖZET}

Inşaat firmalarında uluslararasılaşma küresel rekabeti içeren önemli bir stratejik karardır. Küreselleşmeye bağlı olarak, inşaat sektörü de dahil omak üzere tüm sektörler yüksek rekabet, belirsizlik ve risklerle karşı karşıya kalmışlardır. Uluslararası inşaat sektörü yerel inşaat sektörü ile benzer riskler içermesinin yanı sıra, projenin gerçekleştirildiği ülkeye özgü riskleri de içermektedir. Bu riskler uluslararası projelerin performansları üzerinde büyük etkiye sahiptir. Uluslararası yüklenicilerin sürdürülebilir rekabet avantajı sağlamaları büyük ölçüde bu risklerin doğru bir şekilde yönetilmesine bağlı olduğu için, bu risklerin değerlendirilmeleri firmaların başarısı için hayati bir önem taşımaktadır. Bu çalışmanın ana amacl; uluslararası inşaat sektörü kapsamında proje gerçekleştirilmek üzere gidilen ülkenin kendine özgü risklerinin analiz edilmesidir. Bu riskler kapsamlı bir literatür taraması sonucunda belirlenmiş va kategorize edilmiştir. Bu amaçla, yapım yönetimi literatürünün en saygın dört dergisinde 2000-2010 yılları arasında konu ile ilgili yayınlanmış makaleler taranmıştır. Bu dört süreli yayın sırasıyla; Journal of Construction Engineering and Management, Journal of Management in Engineering, Construction Management and Economics ve International Journal of Project Management adlı dergilerdir. Ülkeye özgü risklerin doğru bir şekilde değerlendirilmesinin uluslararası yüklenicilerin karlıı̆̆ı üzerindeki etkilerinin taranan makalelerde vugulanan ortak noktadır. Bu nedenle, bu çalışma kapsamında uluslararası inşaat risk değerlendirme modelleri de incelemiştir. Sonuç olarak, literatür taraması ışı̆ııda belirlenen proje gerçekleştirilmek üzere gidilen ülkeye özgü 18 risk faktörü arasından sırasıyla; politik stabilite, hukuk ve kanunlar, döviz kuru riski, kültürel farklılıklar, enflasyon, kamusallaştırma, farklı vergi ödemeleri, dil farklılığı, rüşvet ve yolsuzluk, mücbir sebepler ve sosyal karışıklıkların en önemli risk kriterleri olduğu belirlenmiştir. Bu çalışma sonucunda elde edilen veriler daha sonra uluslararası inşaat projeleri için geliştirilecek olan risk değerlendirme modellerinde kullanılabilir.

'Mimar Sinan Fine Arts University, Istanbul, Turkey; ${ }^{2}$ Yıldız Technical University, Istanbul, Turkey.

'Mimar Sinan Güzel Sanatlar Üniversitesi, İstanbul; ${ }^{2} Y$ IIdız Teknik Üniversitesi, İstanbul.

Article arrival date: May 05, 2014 (Başvuru tarihi: 05 Mayıs 2014) - Accepted for publication: June 05, 2014 (Kabul tarihi: 05 Haziran 2014)

Correspondence (iletişim): Güzin AYDOGAN. e-mail (e-posta): aydoganguzin@hotmail.com

๑ 2014 Yıldız Teknik Üniversitesi Mimarlık Fakültesi - @ 2014 Yıldız Technical University, Faculty of Architecture 
$\mathrm{C}$

onstruction industry which is the leading sector in domestic market has also become one of the leading sectors in global market. Approximately $8 \%$ of the global gross domestic product (GDP) depends on construction industry. This situation is already state the importance of construction industry in global economy. Consequently, construction firms become large sized companies and seek for new opportunities and projects in other countries. Medium and large sized contractors face with risks that are related to the host country during internationalization. International contractors usually lose profit due to poor analysis of the host country related risk factors and lack of an appropriate risk assessment methodology. Therefore, it is vital to determine and analyze the risks in international construction that are related to the host country in order to develop an appropriate risk assessment methodology.

Host country related risk factors are defined with the term 'country risk' in literature has become a research topic in international business over the last two decades and a major concern for the international financial community due to the increasing incidence of debt rescheduling in the early 1980s in developing countries (Cosset and Roy 1991 cited in Hoti and McAleer 2004). It has been generally indicated by researchers in international business management that; fiscal management, entry decisions into a specified country, selection of the entry mode, the project, and the appropriate partner are affected by the policy of the host government, macroeconomic conditions such as; exchange rate, inflation, tax regimes and legal environment of the host country (Nielsen 2007; Desbordes 2007; Berry 2006; Lopez-Duarte and Vidal-Suarez 2010). Global firms usually enter new markets in less developed countries in order to gain competitive advantage and tend to establish partnerships in order to avoid the effects of the host country related risk factors (Shan 1991 cited in Reus and Ritchie 2004). In this respect, global firms usually use international joint venture (IJV) as a tool to reduce the political, economic and social risks of the host country. However, host country related risk factors continue to be global firms' concern while establishing and operating an IJV.

Country risk involves public institutions and policies created by governments as a framework for economic, legal and social relations. Environmental uncertainty becomes apparent due to the probability of host country related risk factors. Country related political, social and economic risk factors are the main determinants of country risk. Country risk originates from unpredictable government policies, the strength of country's legal system, force majeure and economic risks such as inflation, exchange rate and etc. Briefly, country risk can be defined as the risk that economic, social and political events in a country would adversely affect the financial profits of a company (Vij 2005; Oetzel et al. 2001; Nielsen 2007).

On the other hand, country risk is often identified with sovereign risk. Sovereign risk is associated with problems in a country's balance of payments (Schroder 2008). Sovereign risk emerges when a sovereign government repudiates its overseas obligations, and when it avoids corporations and/or individuals from fulfilling such obligations due to economic, financial or political reasons (Ghose 1988 cited in Hoti and McAleer 2004; Haque 2008). Sovereign risk also emerges even though the host country is in a financial position to meet its obligations and where countries encountering genuine difficulties in meeting their obligations. Consequently, country risk can be defined as the likelihood that a sovereign government fails to meet its obligations towards foreign lenders or investors (Hoti and McAleer 2004). In an example; due to global economic crisis, Dubai government announced that it would ask creditors of Dubai World to postpone debt repayments for six months in 2009. This financial crisis had serious impact on the construction sector in Dubai. The construction of the Nakheel (the world's tallest building) had stopped as a consequence of this financial crisis. Recently, international contractors have faced problems due to government changes and internal conflicts in Libya. All construction projects had come to an end and contractors had serious problems in taking their labor back to Turkey and maintaining security around construction side.

Government default on payments, a devaluation of the local currency and an increase in interest rates may cause uncertainties in macroeconomic environment. The aforementioned economic risks have negative effects on the financial performance of IJVs operating in the emerging market. Government and political instability, corruption in the host country, and restrictions on repatriation of profits may cause uncertainties in political environment. That's why; it is vital to assess the host country related risk factors since, they have effects on the supply and cost of international capital flows (Brewer and Rivoli 1990 cited in Hoti and McAleer 2004).

There are country risk rating agencies that evaluate host country related economic, financial, and politi- 
cal risk factors and their interactions in order to state the risks of a particular country. Standard and Poor's, Economist Intelligence Unit, Euromoney, Institutional Investor, International Country Risk Guide, Moody's, and Political Risk Services are the country risk rating agencies. These risk rating agencies provide a composite risk rating including alternative measures of economic, political and financial risk ratings of countries. The primary function of country risk ratings is to concern the possibility of debt repudiation, default or delays in payment by sovereign government or borrowers (Burton and Inoue, 1985 cited in Hoti and McAleer 2004). However, country risk ratings are unreliable predictors of future volatility even though the analyses can be defined as a significance of a well-established field within international business (Oetzel et al. 2001). Since the measures of these ratings are unreliable in predicting future volatility, international contractors can't rely on these ratings while evaluating the risks of a specific country. For this reason, it is vital to find out the risks related to the host country that effect the construction industry in order to assess the effects of these risks and avoid the loses that emerge as a result of these affects. In this respect, a literature review is conducted in order to determine the host country related risk factors in international construction by using meta-analysis technique. The ratings of the risk factors are also revealed due to the results of this study. Besides determining the host country related risk factors and their ratings, this study also covers an overview of the international construction literature for the period of 2000-2010. This review allows realizing the importance of host country related risk factors in international construction risk assessment models as well as summarizes the main topics of international construction literature.

Within the context of this study, the process of the determining of the host country related risk factors by using meta-analysis and the risk assessment models that were developed for the period of $2000-2010$ is explained in detail.

\section{Meta Analysis}

Meta-analysis is selected as the most effective tool for this study. Meta-analysis allows reinterpretation of previous results, and it is frequently used in construction management research. Glass (1976) defined meta-analysis as follows;

"Meta-analysis refers to the analysis of analyses.. . the statistical analysis of a large collection of analysis results from individual studies for the purpose of inte- grating the findings. It connotes a rigorous alternative to the casual, narrative discussions of research studies which our attempts to make sense of the rapidly expanding research literature." (cited in Kenley, 1998)

A literature review is conducted by using meta-analysis technique in order to determine host country related risk factors that affect international construction projects within the context of this study. Four most respected journals of construction management literature were reviewed including; Journal of Construction Management and Engineering, Journal of Management in Engineering, Construction Management and Economics, and International Journal of Project Management for the period of 2000-2010. Table 1 presents the subject and the methodology of the reviewed papers.

The term "international construction risks" and the term "international project risks" are searched in ASCE Database within the two journals; Journal of Construction Management and Engineering, and Journal of Management in Engineering for the period of 2000-2010. Three articles were found including the term "international construction risks" in title, and three articles were found including the term "international construction risks" in keywords. One article was found containing the term "international project risks" in title. In addition, one article was found containing the "entry decision" in title. As a result; eight articles were selected in order to determine the international construction risk factors that are related to the host country due to the search in ASCE database.

The term "international construction risks" and the term "international project risks" are searched in Science Direct Database within the context of International Journal of Project Management for the period of 2000-2010. Eleven articles were found with several topics. Then, the topic of the articles was limited with the term "IJV performance" and the term "political risk". Two articles were found through this search.

The term "international construction risks" and the term "international project risks" are searched in Taylor and Francis Database within the journal Construction Management and Economics for the period of 20002010. Two articles were found through the search in Taylor and Francis Database. Two more articles were selected due to their relevancy with the terms "entry decision" and "host country related risks".

Three articles that published before 2000 were added to the list due to cross references. Zhi (1995) is one the most cited study which argues the risk manage- 
Table 1. Papers associated with internationalization that have been published in construction management literature for the period of 2000-2010

\begin{tabular}{|c|c|c|c|c|}
\hline Writers & Year & Journal & Subject & Research methodology \\
\hline Ashley and Bonner & 1987 & JCEM & RA/ RM_Political Risks & Case Study \\
\hline Zhi, H & 1995 & IJPM & RAM & AHP_PI \\
\hline Bing, L. et al. & 1999 & JCEM & $\mathrm{RA} / \mathrm{RM}$ & Likert Scale 1-5 \\
\hline Hastak and Shaked & 2000 & JME & RAM & AHP \\
\hline Han and Diekmann & $2001 a$ & JCEM & go/no-go decision & Risk based-Analytical \\
\hline Han and Diekmann & $2001 b$ & CME & go/no-go decision & $\mathrm{CIA}$ \\
\hline Kapila and Hendrickson & 2001 & JCEM & RM/Exchange risk & Case Study \\
\hline Mohamed & 2003 & JCEM & $\mathrm{RA}$ & SEM \\
\hline Wang et al. & 2004 & CME & RAM & Alien eyes' risk model \\
\hline Dikmen and Birgonul & 2004 & JCEM & Entry Decision & Neural Network \\
\hline Han et al. & 2004 & JCEM & $\mathrm{RM}$ & Case Study \\
\hline Han et al. & 2005 & JCEM & RM & $\mathrm{ClA}$ \\
\hline Gunhan and Arditi & 2005 & JCEM & RM & AHP_Delphi \\
\hline Ozorhon et al. & 2007 & IJPM & RA & Likert Scale 1-5 \\
\hline Khattab et al. & 2007 & IJPM & Political Risks & Likert Scale 1-5 \\
\hline Chen & 2008 & CME & Entry mode selection & Binary log.reg. analysis \\
\hline Jha and Devaya & 2008 & CME & RA & ISM \\
\hline
\end{tabular}

RA: Risk analysis; RM: Risk management; RAM: Risk assessment model.

ment for overseas construction projects. Ashley and Bonner (1987) is also the first study which concerns the effects political risks in international construction. Bing et al. (1999) is one of the first studies that analyses the risks for international construction projects.

As a result; seventeen articles were selected in order to determine host country related risk factors and their priorities in international construction. Eighteen host country related risk factors were determined through literature review. The results of the literature review of host country related risk factors in construction management are presented in Table 1.

\section{Risk Assessment Models in International \\ Construction}

International contractors usually get involved in projects in developing countries. Developing countries are characterized by dynamic and complex environments due to existing risks such as government instability, tax discrimination, high level of inflation, currency fluctuations, legal restrictions and shortages of adequately trained craftsmen. Researchers have pointed out the negative effect of the failure in assessing political, economic, cultural, and legal environment of a project on the profitability of firms in a foreign market (Ashley and Bonner 1987; Han et al. 2005; Abdelghny and Ezeldin 2010).
International construction risk assessment models, go/no go decision models, entry decision models in international construction market, and the effects of host country related risk factors on the performance of international construction projects are the main topics of literature.

Zhi (1995) developed a risk assessment model for international construction projects by using Analytical Hierarchy Process (AHP). The developed by Zhi (1995) allows managing various risks by combining risk probability analysis with risk impact assessment. International construction risks are categorized in four main groups including; nation/region, construction industry, company and project within the context of the study by Zhi (1995). High inflation rates, bureaucracy, low social security, corruption, lack of education facility nearby, lack of transportation, facility nearby, tax rate changes, exchange rate fluctuation, lack legal system, and lack of communication facility nearby are found to be the most important risk factors in international construction projects (Zhi 1995).

The study by Bing et al. (1999) is one of the first studies in literature that identified the risks for international construction. 11 host country related risk factors were determined among 25 risk criteria within the context of this study including; inconsistency in policies, laws, and regulations, economy fluctuation, 
Table 2. Host country related risk factors in construction management literature

\begin{tabular}{|c|c|c|c|c|c|c|c|c|c|c|c|c|c|c|c|c|c|c|}
\hline $\begin{array}{l}\text { References } \\
\text { Host Country } \\
\text { Related Risk Factors }\end{array}$ & 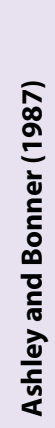 & 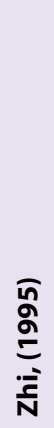 & 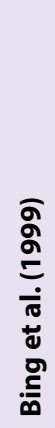 & 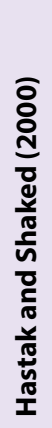 & 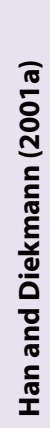 & 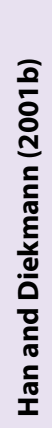 & 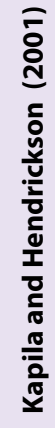 & 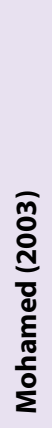 & 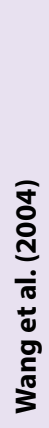 & 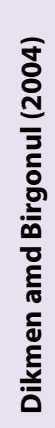 & 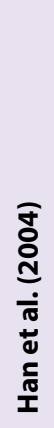 & 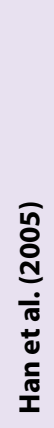 & 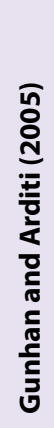 & 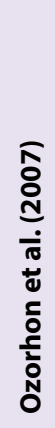 & 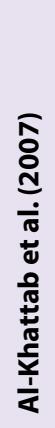 & 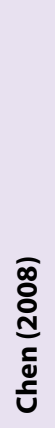 & 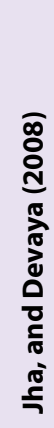 & $\begin{array}{l}\bar{J} \\
\stackrel{0}{0} \\
\stackrel{2}{0}\end{array}$ \\
\hline Inflation & & $\sqrt{ }$ & $\sqrt{ }$ & $\sqrt{ }$ & $\sqrt{ }$ & $\sqrt{ }$ & $\sqrt{ }$ & & $\sqrt{ }$ & & $\sqrt{ }$ & & $\sqrt{ }$ & $\sqrt{ }$ & & & & 10 \\
\hline Exchange Rate Risk & $\sqrt{ }$ & $\sqrt{ }$ & $\sqrt{ }$ & $\sqrt{ }$ & $\sqrt{ }$ & $\sqrt{ }$ & $\sqrt{ }$ & & $\sqrt{ }$ & & $\sqrt{ }$ & & $\sqrt{ }$ & $\sqrt{ }$ & $\sqrt{ }$ & & $\sqrt{ }$ & 13 \\
\hline GDP & & $\sqrt{ }$ & $\sqrt{ }$ & $\sqrt{ }$ & & & $\sqrt{ }$ & & & $\sqrt{ }$ & & & & & & $\sqrt{ }$ & & 6 \\
\hline Tax Discrimination & $\sqrt{ }$ & $\sqrt{ }$ & & & $\sqrt{ }$ & $\sqrt{ }$ & $\sqrt{ }$ & & & & & & & & $\sqrt{ }$ & $\sqrt{ }$ & & 7 \\
\hline Interest Rate & & & & & & & & & $\sqrt{ }$ & & $\sqrt{ }$ & & $\sqrt{ }$ & & $\sqrt{ }$ & & $\sqrt{ }$ & 5 \\
\hline Restriction on Profit Transfer & & & $\sqrt{ }$ & & $\sqrt{ }$ & $\sqrt{ }$ & $\sqrt{ }$ & & & & & $\sqrt{ }$ & & $\sqrt{ }$ & & & & 6 \\
\hline Political Stability & $\sqrt{ }$ & $\sqrt{ }$ & $\sqrt{ }$ & $\sqrt{ }$ & $\sqrt{ }$ & $\sqrt{ }$ & $\sqrt{ }$ & $\sqrt{ }$ & $\sqrt{ }$ & $\sqrt{ }$ & $\sqrt{ }$ & $\sqrt{ }$ & $\sqrt{ }$ & $\sqrt{ }$ & $\sqrt{ }$ & $\sqrt{ }$ & $\sqrt{ }$ & 17 \\
\hline Expropriation; Nature and & $\sqrt{ }$ & & & $\sqrt{ }$ & $\sqrt{ }$ & $\sqrt{ }$ & & $\sqrt{ }$ & $\sqrt{ }$ & & & & & & $\sqrt{ }$ & $\sqrt{ }$ & & 8 \\
\hline Extend of Nationalism & & & & & & & & & & & & & & & & & & \\
\hline Bureaucracy & & & & $\sqrt{ }$ & & & & $\sqrt{ }$ & & & & & & & & & & 2 \\
\hline Entry Restrictions & & & $\sqrt{ }$ & & & & $\sqrt{ }$ & & $\sqrt{ }$ & & & $\sqrt{ }$ & & & $\sqrt{ }$ & $\sqrt{ }$ & & 6 \\
\hline Socio-economic Stability & & & & $\sqrt{ }$ & & & $\sqrt{ }$ & & $\sqrt{ }$ & & & $\sqrt{ }$ & & & $\sqrt{ }$ & & & 5 \\
\hline Law and regulations & $\sqrt{ }$ & $\sqrt{ }$ & $\sqrt{ }$ & $\sqrt{ }$ & $\sqrt{ }$ & $\sqrt{ }$ & $\sqrt{ }$ & $\sqrt{ }$ & $\sqrt{ }$ & $\sqrt{ }$ & $\sqrt{ }$ & $\sqrt{ }$ & $\sqrt{ }$ & $\sqrt{ }$ & $\sqrt{ }$ & $\sqrt{ }$ & $\sqrt{ }$ & 17 \\
\hline Hostilities With Neighboring & $\sqrt{ }$ & $\sqrt{ }$ & & $\sqrt{ }$ & & & & & & & & & & & & & & 3 \\
\hline Country & & & & & & & & & & & & & & & & & & \\
\hline Societal Conflicts & $\sqrt{ }$ & $\sqrt{ }$ & $\sqrt{ }$ & $\sqrt{ }$ & $\sqrt{ }$ & $\sqrt{ }$ & & & & & & & & & $\sqrt{ }$ & & & 6 \\
\hline Cultural Differences & & $\sqrt{ }$ & $\sqrt{ }$ & $\sqrt{ }$ & $\sqrt{ }$ & $\sqrt{ }$ & & $\sqrt{ }$ & $\sqrt{ }$ & $\sqrt{ }$ & & $\sqrt{ }$ & $\sqrt{ }$ & & $\sqrt{ }$ & $\sqrt{ }$ & $\sqrt{ }$ & 13 \\
\hline Language Barrier & & $\sqrt{ }$ & $\sqrt{ }$ & $\sqrt{ }$ & $\sqrt{ }$ & $\sqrt{ }$ & & $\sqrt{ }$ & $\sqrt{ }$ & & & & & & & $\sqrt{ }$ & & 8 \\
\hline Bribery and corruption & & $\sqrt{ }$ & & $\sqrt{ }$ & & & & $\sqrt{ }$ & $\sqrt{ }$ & & & $\sqrt{ }$ & $\sqrt{ }$ & & & & $\sqrt{ }$ & 7 \\
\hline in the Host Country & & & & & & & & & & & & & & & & & & \\
\hline Force Majeure & & $\sqrt{ }$ & $\sqrt{ }$ & & $\sqrt{ }$ & $\sqrt{ }$ & & & $\sqrt{ }$ & & & & & & $\sqrt{ }$ & & $\sqrt{ }$ & 7 \\
\hline
\end{tabular}

exchange rate, force majeure and social disorder, inflation, restrictions on fund repatriation, import restriction, security problems, language barrier, cultural differences and pollution. These risks factors were compared in terms of their relative weights of impact on international construction projects.

Hastak and Shaked (2000) have developed a risk assessment model for international construction. According to this model there are three levels of risk including; macro (or country) level, market level and project level. In this risk assessment model host country related risk factors are defined as the macro risk. The macro (country) level defines the general risk which international contractors face while expanding operations in a specific country. The market level risk defines the risk associated with a specific interna- tional construction market. The market level risk also includes the impact of the macro level risk on the construction market. The project level defines the risk associated with a specific project in a specific country, which includes the impact of the macro and market levels on the project. The model is based on the analytical hierarchy process. The framework of the study is as shown in Figure 1. Hastak and Shaked (2000) proposed that this risk assessment model can be used as a tool to quantify the risk involved in an international construction project in a specific country. This model provides four main results including; high risks indicators, impact of country environment on a specific project, impact of market environment on a specific project and overall project risk. According to Hastak and Shaked (2000); the developed model allows the decision makers to evaluate the potential risk at the 
macro, market and construction project levels by using available information, knowledge, and expertise.

Country level risks were found to have almost high, market level risks were found to have moderate high, and project level risks were found to have moderate risks due to the results of the study by Hastak and Shaked (2000). Political continuity, enforceability of contracts, monetary inflation, economic growth, administration bureaucratic delays, communication and transportation, professional services other than construction, dependence on or importance of major power, fragmented political structure, fractionalization by language, ethnic, and regional groups, restraints to retaining power, mentality (nationalism, corruption, and dishonesty), social conditions (e.g., population density and wealth distribution), symptoms of instability, societal conflicts (e.g., demonstrations, strikes, and street violence), instability because of non-constitutional changes, financial risk legal framework, foreign exchange generation, current account balance, capital flow, international reserves, foreign exchange reserves, gold and other reserves, foreign debt assessment, debt as GDP converted to U.S. dollars, budget performance extent of deficit / surplus, and sources of revenue and major spending are found to have high risk on international construction market.

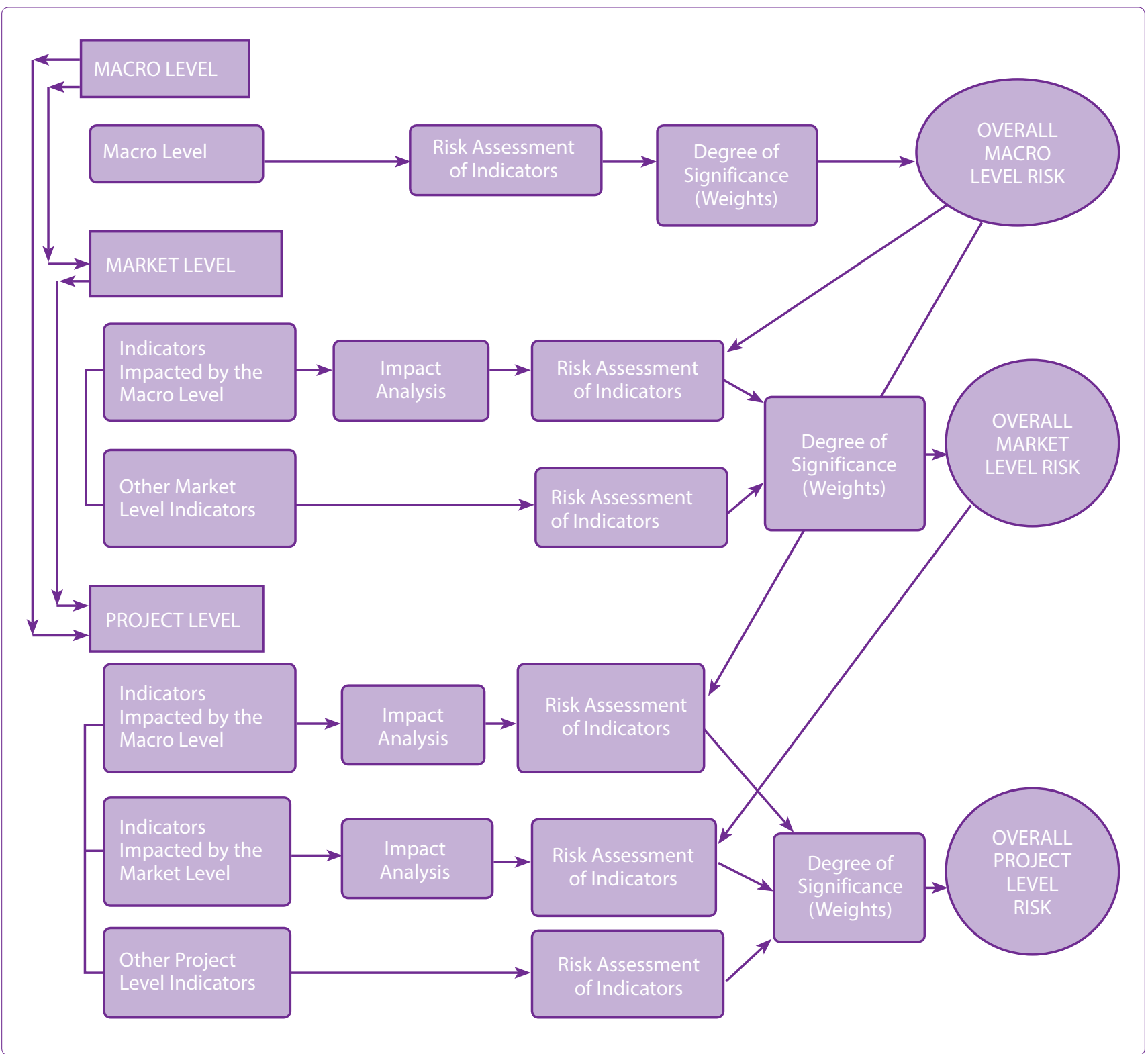

Figure 1. Framework of ICRAM Developed by Hastak and Shaked (2000). 
Wang et al. (2004) developed a risk management framework for construction projects in developing countries. Risks associated with international construction are identified in three main groups including; country level, market level and project level within the context of this study. Approval and permit change in Law, justice reinforcement, local partner's creditworthiness, political instability, cost overrun, corruption, inflation and interest rates, government policies, gov- ernment influence on disputes and termination of JV are found to be the most important risk factors for construction projects in developing countries. Findings of the study by (Wang et al. 2004) and (Hastak and Shaked, 2000) are similar since, the risks at country level are found to be more critical than that at market and project levels due to the results of each study.

On the other hand; go/no go decision models are one of the research areas of international construction

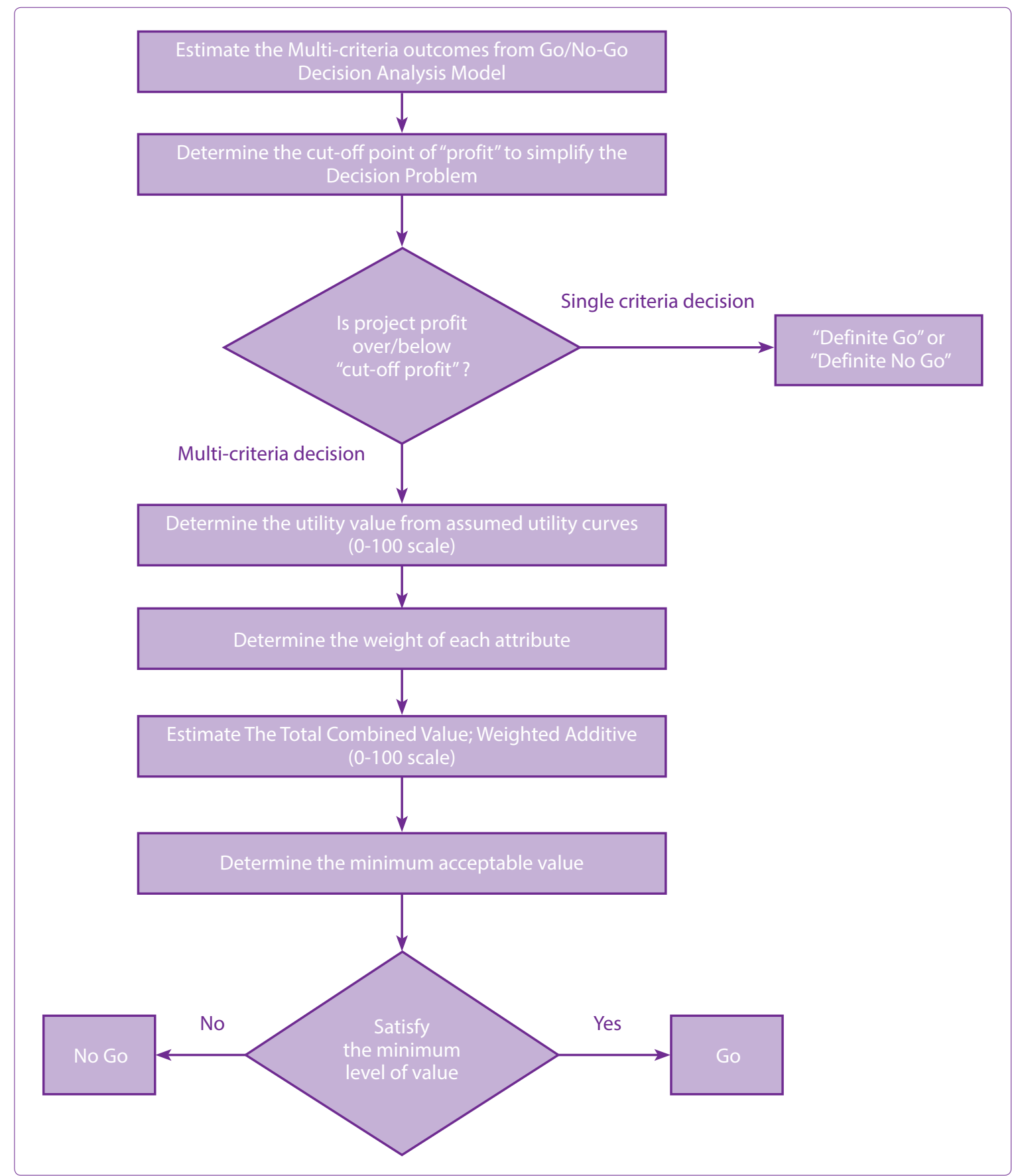

Figure 2. Go-No Go Decision Process Model Developed by Han and Diekmann (2001a). 
literature. Han and Diekman (2001a) have developed a go/no go decision model for international construction projects based on cross impact analysis. The developed go/no go decision process model for international construction is illustrated in Figure 2.

The Cross Impact Analysis has been selected as a tool since; it is a powerful technique to deal with vague uncertainty and circumstances that are judgementally intensive but have poor data. Han and Diekmann (2001a) proposed that the developed model is fundamentally a risk-based, normative model. Besides, go/no-go decision models researchers paid attention to entry decision models, since the decision to enter a new foreign market is of critical importance to the company's profitability and sustainable growth and the effects of host country related risk factors differ from country to country. Dikmen and Birgonul (2004) have developed a neural network model as a decision support tool that is dealing with the attractiveness and the competitiveness of international construction projects. Availability of funds, market volume, economic prosperity, contract type, and country risk rating are found to be most important factors that increase the attractiveness of an international construction project due to the results of the developed model. The study by Dikmen and Birgonul (2004) also proposed that level of competition, attitude of host government, existence of strict quality requirements, country risk rating, and cultural/religious similarities are the most important factors that affect competitiveness of international contractors in global market. Gunhan and Arditi (2005) evaluated the relative importance of company strengths associated with international expansion and the threats and opportunities related to international market and proposed a model that is presented in Figure 3.

The proposed model consists of two main steps. The first step concerns the analysis of the internal and external readiness of a company whether it needs to expand into international markets, and whether it has the resources and organization to realize such an expansion. The second step of the model is associated with identifying the relative importance of strengths of companies as well as the threats and opportunities associated with international construction by applying AHP and Delphi method. Gunhan and Arditi (2005) pro-

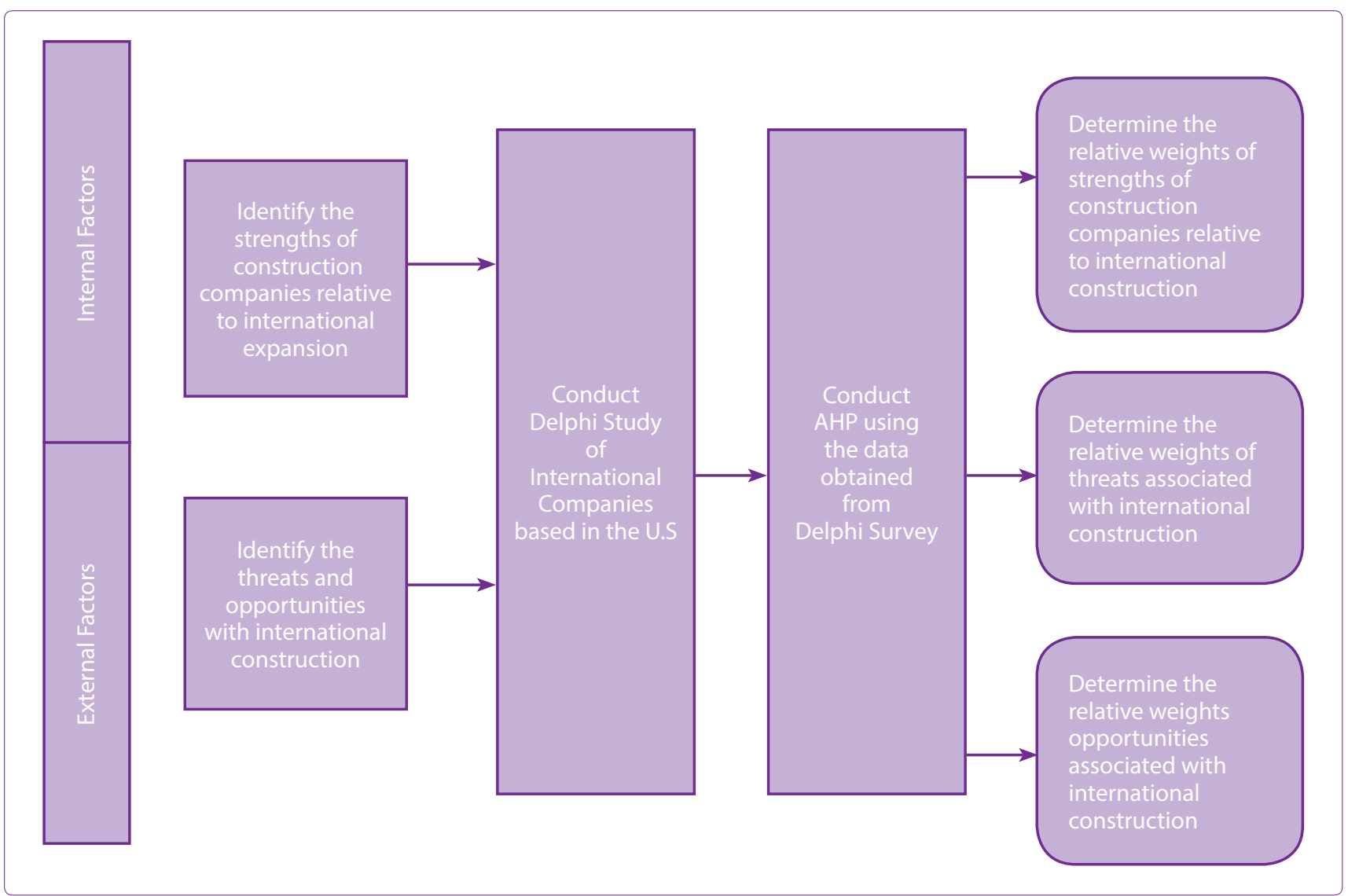

Figure 3. Flow Chart of the Foreign Market Entry Decision Model Developed by Gunhan and Arditi (2005). 
posed that the developed model enables executives to make a decision in case of expanding their business into international markets into a specific country.

Chen (2008) developed a statistical model for entry mode selection for international construction markets. A regression model was developed that describes the practices of international contractor's in entry mode selection. According to the results of the study by Chen (2008); international contractors do not tend to determine entry mode based on trade link, investment risk and host market attractiveness. The results of this study also show that international contractors are more likely to use permanent entry than mobile entry when cultural distance or competitive intensity is significant or colonial link, language proximity or entry restriction is insignificant. Chen and Messner (2009) tested the impacts of some host country related factors upon the selection between permanent entry and mobile entry to provide both theoretical and practical implications about entry mode selection for international construction markets. Within this study, a regression model was developed in order to describe the international contractor's practices in entry mode selection. The hypotheses of the study are based on cultural difference, trade link, host market potential, language proximity, investment risk, entry restriction, and competition intensity. The results of statistical analysis also showed that international contractors appear to be adventurous risk-takers and aggressive competitors. International contractors usually use mobile entry modes, but also prefer permanent entry modes in order to gain local knowledge, purchase new capabilities and establish local networks to overcome the challenges in the host country market (Chen 2008; Chen and Messner 2009). International contractors establish joint ventures as a permanent entry mode with a local firm in order to reduce risks related to the host country and gain competitiveness in international market. That's why; international construction joint venture (ICJVs) is one of the main topics of literature. The effects of host country related risk factors on the performance of ICJVs have also been discussed by researchers (Kapila and Hendrickson 2001; Ozorhon et al. 2007).

\section{Conclusions}

Several risks that are related to host country have effects on international construction. Since appropriate risk management is essential for the performance of international construction projects and competitiveness of international contractors, identification of these risks and development of risk assessment mod- els becomes important. In this respect, a meta-analysis is conducted within the context of this study in order to determine the host country related risk factors and their priorities in international construction. The result of this meta-analysis is presented in Table 2 shows the ratings of host country related risk factors in construction management literature.

Besides the rating of host country related risk factors in literature (Table 2), the other main finding of this study is that; the proper assessment of host country related risks factors including political, economic and social risks has direct effects on the profitability of international contractors and the performance of international construction projects. Therefore, this study also covers a review of risk assessment models for international construction in order to compare the methodology and the outcomes of these studies. The effects of host country related risk factors also realized through go/no-go decision models. The majority of these risk assessments models classify the risks of international construction projects in three main groups including; country, market/industry and project levels. AHP and P-I method is the common methodology of the developed risk assessment models. AHP is selected as one of the most appropriate tool for risk assessment models, since it allows analyzing the hierarchy of risk factors for each level and determining the relative importance weight of risk factors among all.

Table 3. Ratings of host country related risk factors

\begin{tabular}{lc}
\hline Risk factors & Ratings \\
\hline Political Stability & 17 \\
Law and regulations & 17 \\
Exchange Rate Risk & 13 \\
Cultural Differences & 13 \\
Inflation & 10 \\
Expropriation & 8 \\
Tax Discrimination & 7 \\
Language Barrier & 7 \\
Bribery and corruption in the host country & 7 \\
Force majeure & 6 \\
Societal conflicts & 6 \\
GDP & 6 \\
Restrictions on profit transfer & 5 \\
Entry restrictions & 5 \\
Socio-economic Stability & 5 \\
Interest rate & 5 \\
Hostilities with neighboring country & 3 \\
Bureaucracy & 2 \\
\hline
\end{tabular}


Law and regulations in the host country and political stability in the host country is the most cited host country related risk factor in construction management literature with the rating of 17 . Exchange rate risk and cultural differences have the rating of 13 where inflation has the rating of 10 . Expropriation has the rating of 8 where tax discrimination, bribery and corruption, and language barrier in the host country has the rating of 7. The following risk factors; GDP, force majeure and internal/external conflicts in the host country have the rating of 6 . Socio-economic stability, interest rate, entry restrictions and restrictions on profit transfer has the rating of 5 .

Political risks are the most cited risk factors in international construction literature, since law and regulations and political stability have the highest rating among host country related risk factors in literature and cited in each article that has been reviewed. Exchange rate and cultural difference is also found to be the other important risks in international construction. Exchange rate risk has serious effects on the profits of international contractors, since it is defined in the clauses of contracts. On the other hand, cultural differences has become one of the main topics of international construction and sometimes defined with the term "cross-cultures" in literature. Economic risks of the host country including; inflation with the rating of 9 and tax discrimination with the rating of 8 are the following risk factors.

Since there are numerous risk factors that are related to the host country, it is essential to identify the most important risk factors while developing risk assessment model that would be useful for decision makers. In this respect, the results of this study can be used as a data in further studies that are associated with risk assessment models for international construction.

\section{References}

1. Ashley, B.D. and Bonner, J.J. (1987). "Political Risks in International Construction", Journal of Construction Engineering and Management, 113(3), 447-467.

2. Berry, H., (2006). "Shareholder Valuation of Foreign Investment and Expansion", Strategic Management Journal, 27, 1123-1140.

3. Bing, L., Tiong, R.L-K., Fan, W.W., and Chew, D.A-S. (1999), " Risk Mangement In International Construction Joint Ventures", Journal of Construction Engineering and Management, 125(4), 277-28.

4. Chen, C. (2008). "Entry mode selection for international construction markets: the influence of host country related factors", Construction Management and Economics, 26, 303-314.
5. Chen, C. and Messner, J.I., (2009). "Entry Mode Taxonomy for International Construction Markets", Journal of Management in Engineering, 25 (1): 3-11.

6. Desbordes, R., (2007). "The sensitivity of U.S. multinational enterprises to political and macroeconomic uncertainty: A sectoral analysis", International Business Review, 16, 732-750.

7. Dikmen, I. and Birgonul, M.T., (2004). "Neural Network Model to Support International Market Entry Decisions", Journal of Construction Engineering and Management, 130(1): 59-66.

8. Gunhan, S. and Arditi, D. (2005).“Factors Affecting International Construction", Journal of Construction Engineering and Management, 131(3), 273-282.

9. Han, S.H. and Diekmann, J.E. (2001a). "Approaches for Making Risk-Based Go/No-Go Decisions for International Projects", Journal of Construction Engineering and Management, 127(4), 300-308.

10. Han, S.H. and Diekmann, J.E. (2001b). "Making a riskbased bid decision for overseas construction projects", Construction Management and Economics, 19(8), 765776.

11. Han, S.H., Diekmann, J.E. and Ock, J.H. (2004). "Multicriteria Financial Portfolio Risk Management for International Projects", Journal of Construction Engineering and Management, 130(3), 346-356.

12. Han, S.H., Diekmann, J.E. and Ock, J.H. (2005). "Contractor's Risk Attitudes in the Selection of International Construction Projects", Journal of Construction Engineering and Management, 131(3), 283-292.

13. Hastak, M. and Shaked, A. (2000). "ICRAM-1: Model for International Construction Risk Assessment", Journal of Management in Engineering, 16(1), 59-69.

14. Haque, M.A., (2008). "Country Risk Assessment: Risk Assessment of the Developing Countries", Journal of International Business Research, 7 (1): 21-34.

15. Hoti, S. and McAleer, M. (2004). "An Empirical Assessment of Country Risk Ratings and Associated Models", Journal of Economic Surveys, 18(4), 539-588.

16.Jha, K.N. and Deveya, M.N., (2008). "Modelling the Risks Faced by Indian Construction Companies Assessing International Projects", Construction Management and Economics, 26(4): 337-348.

17. Kapila, P. and Hendrickson, C. (2001). "Exchange Rate Risk Management in International Construction Ventures", Journal of Management in Engineering, 17(4), 186-191.

18. Kenley, R (1998) "The role of Meta-Analysis in construction management research". In: Hughes, W (Ed.), 14th Annual ARCOM Conference, 9-11 September 1998, University of Reading. Association of Researchers in Construction Management, (1), 31-8.

19. Khattab, A., Anchor, J. and Davies, E. (2007). "Managerial perceptions of political risk in international projects", International Journal of Project Management, 25, 734-743.

20. Lopez-Duarte, C. and Vidal-Suarez, M.M., (2010). "External Uncertainty and Entry Mode Choice: Cultural Distance, Political Risk and Language Diversity", Interna- 
tional Business Review, 19, 575-588.

21. Mohamed, S. (2003). "Performance in international construction joint ventures: Modeling perspective", Journal of Construction Engineering and Management, 129(6), 619-626.

22. Nielsen, B.B., (2007). "Determining International Strategic Alliance Performance: A Multidimensional Approach", International Business Review, 16, 337-361.

23. Oetzel, J.M., Bettis, R.A. and Zenner, M., (2001). "Country Risk Measures: How Risky Are They?", Journal of World Business, 36 (2): 128-145.

24. Ozorhon, B., Arditi D., Dikmen, I. and Birgonul, M.T. (2007). "Effect of host country and project conditions", International Journal of Project Management, 25, 799806.

25. Reus, T.H., and Ritchie W.J. (2004).“Interpartner, Parent, and Environmental Factors Influencing The Operation of International Joint Ventures: 15 Years of Research", Management International Review, 44(4), 369-395.
26. Schroeder, S.K., (2008). "The Underpinnings of Country Risk Assessment", Journal of Economic Surveys, 22(3), 498-535.

27. Vij, M., (2005). "The Determinants of Country Risk Analysis: An Empirical Approach", Journal of Management Research, 5(1): 20-31.

28. Wang, S.Q., Dulaimi, M.F. and Aguria, M.Y. (2004).“Risk management framework for construction projects in developing countries", Construction Management and Economics, 22(3), 237-252.

29. Zhi, H. (1995). "Risk Management for Overseas Construction Projects", International Journal of Project Management,13 (4), 231-237.

Key words: International construction risks; meta-analysis; country risk; risk assessment models.

Anahtar sözcükler: Uluslararası inşaat riskleri; meta analiz; ülke riski; risk değerlendirme modelleri. 